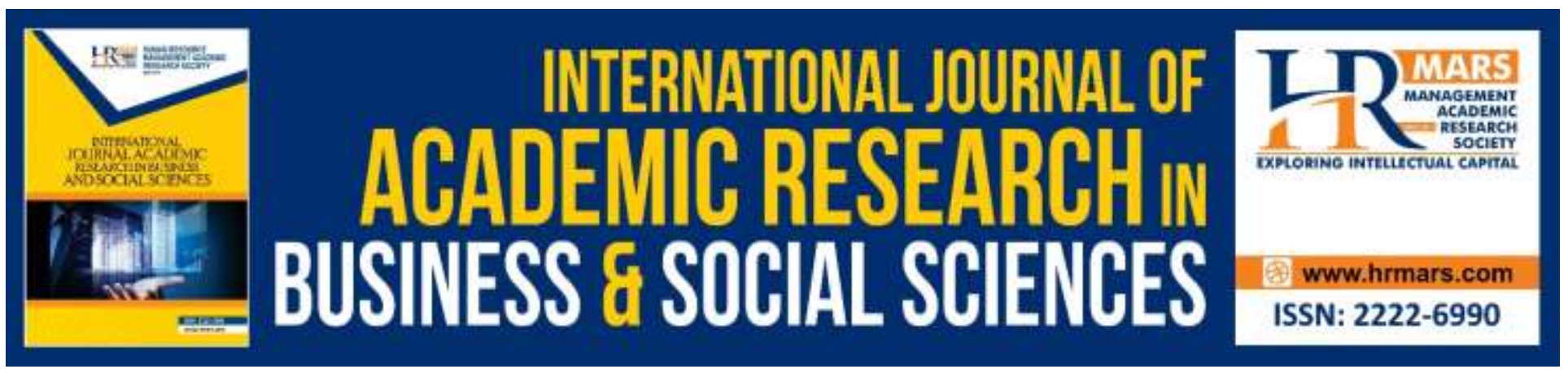

\title{
Factors Affecting Employee Absenteeism in Oil Palm Estate
}

Syahrizan Syahlan, Farahida Zulkefli, Muhammad Zahid Muhammad and Shafiq Sani

To Link this Article: http://dx.doi.org/10.6007/IJARBSS/v10-i4/7112

DOI:10.6007/IJARBSS/v10-i4/7112

Received: 19 February 2020, Revised: 04 March 2020, Accepted: 27 March 2020

Published Online: 13 April 2020

In-Text Citation: (Syahlan et al., 2020)

To Cite this Article: Syahlan, S., Zulkefli, F., Muhammad, M. Z., \& Sani, S. (2020). Factors Affecting Employee Absenteeism in Oil Palm Estate. International Journal of Academic Research in Business and Social Sciences, 10(4), 110-118.

Copyright: (C) 2020 The Author(s)

Published by Human Resource Management Academic Research Society (www.hrmars.com)

This article is published under the Creative Commons Attribution (CC BY 4.0) license. Anyone may reproduce, distribute, translate and create derivative works of this article (for both commercial and non-commercial purposes), subject to full attribution to the original publication and authors. The full terms of this license may be seen

at: http://creativecommons.org/licences/by/4.0/legalcode

\section{Vol. 10, No. 4, 2020, Pg. 110 - 118}

Full Terms \& Conditions of access and use can be found at http://hrmars.com/index.php/pages/detail/publication-ethics 


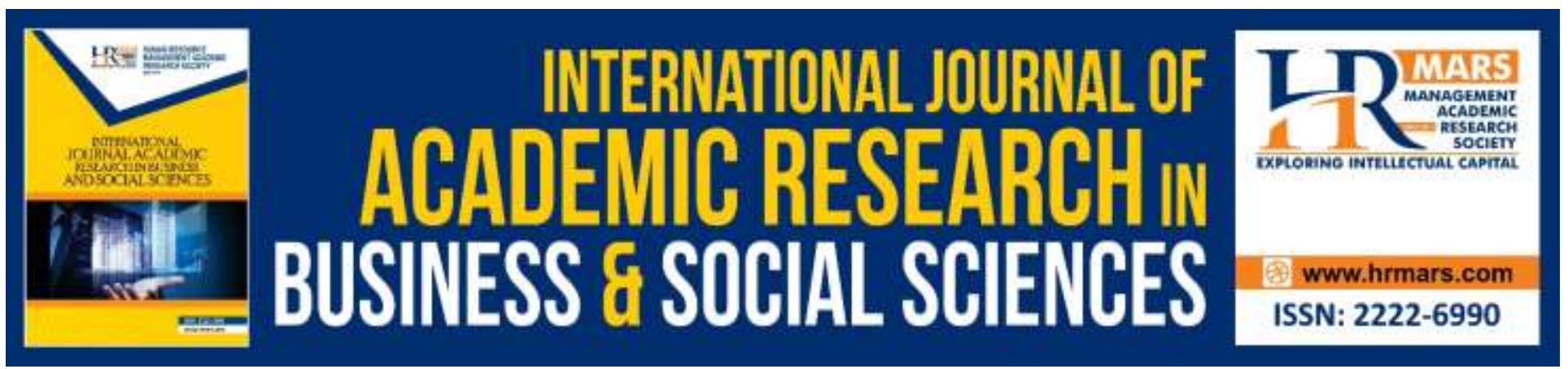

\title{
Factors Affecting Employee Absenteeism in Oil Palm Estate
}

\author{
Syahrizan Syahlan, Farahida Zulkefli, Muhammad Zahid Muhammad \\ and Shafiq Sani \\ Faculty of Plantation and Agrotechnology, Universiti Teknologi MARA (UiTM), Jasin 77300, Melaka \\ Malaysia \\ Email: farahida@uitm.edu.my
}

\begin{abstract}
Employee absenteeism is one of the problems in oil palm plantation. This behavior leads to low productivity and high burdening business cost. This study aims to examine, analyze and explain the influence of stress, family issues, working environment and salary to employee absenteeism in oil palm estate. The primary data used in this study come from questionnaire on respondents' stress, family issues, working environment, salary and employee absenteeism. From 90 people as the population, 73 respondents who met the criteria as a sample were chosen by using the Krejcie and Morgan table. The analytical method used is multiple linear regression analysis using SPSS Version 22. The results of this study indicate that there is a positive and significant influence simultaneously between stress, family issues and working environment on employee absenteeism. Family issues has the highest share and proportion $25.8 \%$ of the variation in employee absenteeism, so it needs special attention. Performance and productivity for estate workers are very crucial to ensure the estate's operation runs smoothly. So, estate manager shall pay special attention to engage their workers.

Keywords: Absenteeism, Oil Palm Estate, Stress, Family Issues, Salary and Working Environment.
\end{abstract}

\section{Introduction}

The oil palm industry is dynamic and often unregulated due to its backbreaking, labored based nature. This makes the task of executing human resource management (HRM) functions more burdensome than in other economic sectors. This is particularly the case for Malaysia which rely heavily on migrant workforce. According to (Farahida, Syahrizan, \& Firdaus, 2018), the highest selection problems that been agreed by most respondents of management were absenteeism (3.74 $\mathrm{MI})$, alcoholism (3.62 $\mathrm{MI})$, and discipline (3.52 $\mathrm{MI})$. Absenteeism is largely viewed as being related to reduced productivity for the overall work atmosphere. In 2018, Malaysian company suffered cost around RM3.28bilion due to workers absenteeism (Tan, 2020). Moreover, an average 67 days per employee reported absent resulted RM2.7million losses in a year (Bernama, 2017). Plus, with a low- 
price crude palm oil (CPO), all these lead to low income and profit. Interest in studying absenteeism has dwindled over the past two decades, and though it has rarely been addressed in the specific context of oil palm sector, it remains an issue of concern for estate managers. As an employer, manager shall be proactive and be a front liner in detecting causes of workers nonattendance in workplace. As matter of fact, estate employees spend their most of daily time in workplace. It is hoping this study can help managers to look their workers welfare and wellbeing.

Hence, the objectives of this study are:

1) To investigate the drivers of absenteeism across harvesters, sprayers and unskilled levels of employees.

2) To examine which issues has the biggest impact to the absenteeism of the employees.

The paper begins with a tour of the literature regarding the structure of employees and the role of HRM in the oil palm industry. The study methodology then follows. Subsequently, the survey results are analyzed. A discussion of these results concludes the paper.

\section{Review Literature}

In the following section, this paper presents the literature describing the hypothesized relationships among various variables of this study.

\section{Employee Absenteeism}

In Malaysia, organizations lose a total of 73.1 days per employee due to absence and presenteeism, costing each employer RM2.27 million per year (AIA, 2018). Absenteeism while driven by micro-level health or job shirking reasons has a macro-level impact in terms of lost productivity. (Hanna, Menches, Sullivan and Sargent, 2005) note that an absence rate of 6-10 per cent decreases productivity by as much as 25 per cent. Identifying the determinants of absenteeism can yield policies that prevent absenteeism driven productivity loss. Findings specific to the construction industry indicate that the nature of the work in terms of long work shifts leads to higher absenteeism rates (Hinze, Ugwu and Hubbard, 1985). In a more recent and wide-reaching study, Drago, R. and Wooden, (2002), using cross-national data from companies in Australia, the USA, Canada and New Zealand, found that stronger group cohesion and high wage levels lead to lower absenteeism. De Paola (2010) also noted that social and group interactions play a significant role in determining absence behavior.

\section{Stress}

Mental health issues in Malaysia are on the rise with $50.2 \%$ of employees having at least one dimension of work-related stress. Statistic shows that $98 \%$ of employees have a higher AIA Vitality Age than actual age and are functioning with a body and mental state that is older than their actual years (AIA, 2018). Stress among workers already hurt Malaysia almost RM RM14.46 billion, or $1 \%$ of Malaysia's Gross Domestic Product (GDP) in 2018 (FMT, 2020). In addition, role ambiguity is experienced when the message that evaluators send are not clear or they give incomplete information (Afzalur, 1996). So, employees who are not clear with their jobs are easy to get stressed because they don't understand what they need to do. 


\section{Family Issues}

Based on Erickson et al. (2010) study, experiencing a high level of burnout was associated with increased absenteeism if employees had children under 6 living at home or reported having difficulty with their child care arrangements. These results have implications for the development of effective family-supportive policies. Hammer (2003) suggest that high levels of family conflict are related to dysfunctional outcomes for the individual, such as life dissatisfaction, anxiety, depression, poor health high levels of work-family conflict lead to increased interpersonal conflict, divorce, and organizations, witness loss of talented employees, tardiness and absenteeism. A person that has many roles in life for example, breadwinner, family member, a church volunteer to name a few, only one of which is typically associated with work (Hellriegel, Slocum \& Woodman, 2001). Role strain or difficulty in meeting role-demands is inevitable and a person must continually make role decisions and bargains in order to meet role requirements (Kreitner and Kinicki, 2004)

\section{Working Environment}

Difficult working conditions prevent a human resource to do his/her job properly. Workers cannot be able to be productive since the lack of infrastructures for the workers to do their job is conducive to the workers' lack of motivation, which will lead to absenteeism in the workstation. Workers need to be working in good environments that are health, wellness, safety, security For Licensed Practical Nurses (LPNs), those working night shifts will have on average $32 \%$ less absenteeism than those working in day shifts. In the case of shift length, only the coefficient for 12 hours shift length for LPNs is significant. LPNs working 12 hours shifts will have on average $51 \%$ more absenteeism than those working 8 hours shifts (Rajbhandary \& Basu, 2010). An international comparison of the effects of sickness benefits on individual absenteeism is provided by (Frick and Malo, 200)). Using cross-section data from the European Survey on Working Conditions they show that individuals tend to be more absent in countries with higher level of sickness benefits. According to Joseph (2015), lack of good working environments can affect employees' morale and prevent them from reporting for their workstation.

\section{Wages}

As wages are the main source of income for the family, the insufficiency in pay impacts on workers morale to work toward the objectives and goals of the organization. Wages are the main source of income for the family and the insufficiency in pay will bring the workers to leave their offices to compensate the wage deficit by the exercise of parallel activities to make both ends meet as wages in the country do not increase simultaneously as the cost of living increases interminably in the country. This brings a limitation to their purchasing power (Joseph, 2015). The econometric analysis of monthly absenteeism in a German company provides evidence that workers are less absent if they enjoy a higher absolute wage, a higher relative wage and are employed at a higher hierarchical level (Pfeifer, 2010)

\section{Materials and Methods}

Conceptual framework is an explanation of the linkage or relationship of a theory with important factors that have been known in a problem. The conceptual framework in this study is built on theoretical views and previous empirical research on correlation between stress, family issues, 
INTERNATIONAL JOURNAL OF ACADEMIC RESEARCH IN BUSINESS AND SOCIAL SCIENCES

Vol. 10, No. 4, April, 2020, E-ISSN: 2222-6990 @ 2020 HRMARS

working environment and wages as well as employee absenteeism. The relationship between variables used in this study can be seen in Figure 1 . The study conducted at 2500 hectares of oil palm estate. Target population in this research were employees of oil palm estate in Selandar Jasin Melaka, which cover all scope of task in, with the total number of samples were 73 people from 90 population based on the population table that was been developed by the Krejcie \& Morgan (1970). Before administering the survey to a full sample of estate sites, a pilot test was carried out.

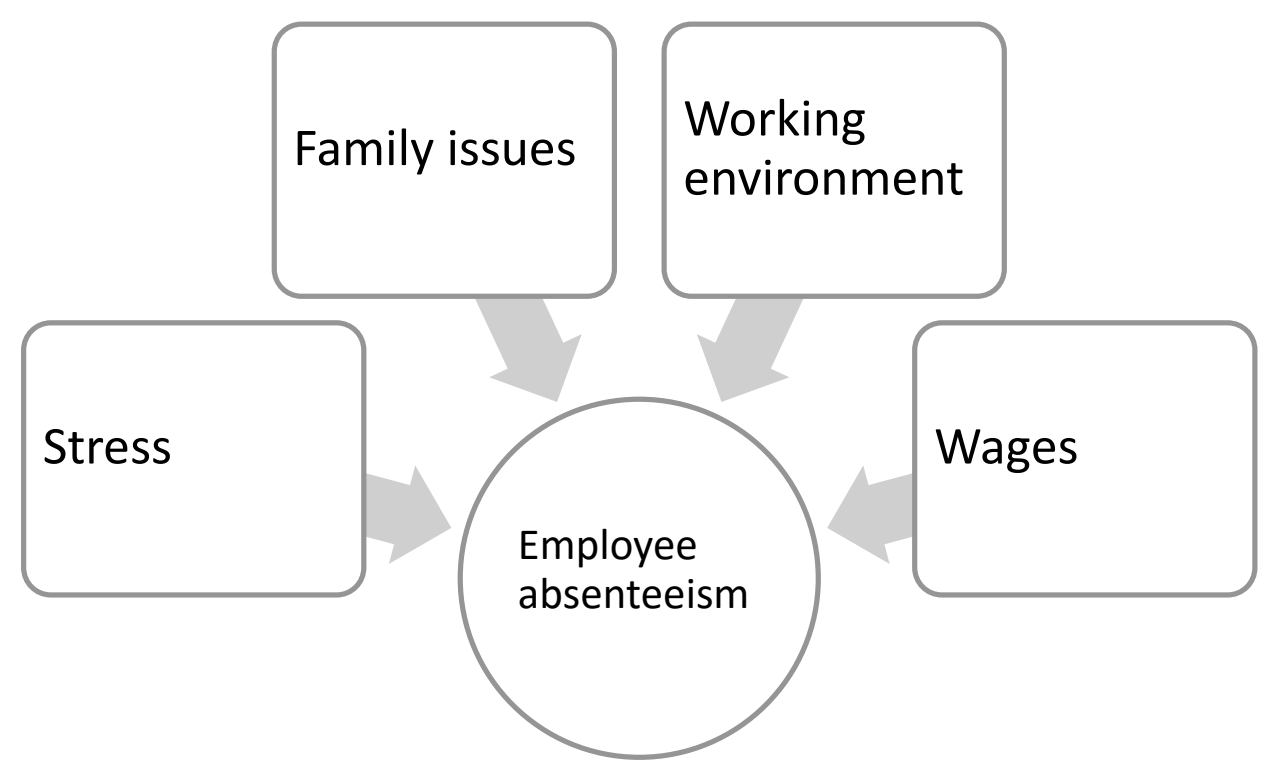

Figure 1: Conceptual framework

\section{Results and Discussion \\ Reliability Test}

From table 1, the results of Cronbach's alpha show a positive consistency on the data when Cronbach's Alpha value estimated was higher than the index of reliability test (0.6). This shows that there is consistency among the workers, and it can be concluded that the study based on the questionnaires is fit for this study Reliability measure how all items in a set questionnaire are positively or negatively to correlated to one another. Previous studied showed the instrument used in the survey should have reliability of 0.7 or more (Nunnaly, 1978). Reliability value less than 0.6 was considered weak and reliability value 0.70 is considered acceptable. Meantime, the Cronbach's alpha has more than 0.8 be considered good and valid (Andale, 2014).

Table 1: Reliability Test

\begin{tabular}{lll}
\hline Variables & Cronbach's Alpha & Status \\
\hline Stress & 0.821 & Reliable \\
Family issues & 0.764 & Reliable \\
Working environment & 0.719 & Reliable \\
Wages & 0.698 & Reliable
\end{tabular}


INTERNATIONAL JOURNAL OF ACADEMIC RESEARCH IN BUSINESS AND SOCIAL SCIENCES

Vol. 10, No. 4, April, 2020, E-ISSN: 2222-6990 @ 2020 HRMARS

\section{Relationship between Factors Contributed to Employee Absenteeism}

Pearson Correlation Analysis was used to identify the relationship between the independent variables (stress, family issues, working environment, wages) that affect the dependent variable (employee absenteeism). The correlation value is as presented in Table 2 below:-

Table 2: Correlation value Interpreted according to Hinkle, Wiersma and Jurs (1988)

\begin{tabular}{ll} 
Correlation Value & Relationship Strength \\
\hline $\pm 0.90-1.00$ & Very Strong \\
$\pm 0.70-0.90$ & Strong \\
$\pm 0.50-0.70$ & Averagely Strong \\
$\pm 0.30-0.50$ & Weak \\
$\pm 0.01-0.30$ & Very Weak \\
0 & No relationship
\end{tabular}

Table 3: Analysis of a Correlation between stress, family issues, working environment salary and employee absenteeism.

\begin{tabular}{llll}
\hline Absenteeism & & & \\
\hline Factors & $\begin{array}{l}\text { Significant } \\
(\boldsymbol{p})\end{array}$ & $\begin{array}{l}\text { Correlation } \\
\text { value } \\
(\boldsymbol{r})\end{array}$ & Relationship strength \\
\hline Stress & 0.004 & $0.801^{* *}$ & Strong \\
Family issues & 0.007 & $0.844^{* *}$ & Strong \\
Working environment & 0.003 & $0.743^{* *}$ & Averagely strong \\
Wages & 0.010 & $-0.653^{* *}$ & Averagely strong
\end{tabular}

From table 3, Pearson Correlation test was conducted. Based on the findings, it was found that family issues showed a high correlation value $r=.844$ compared to other factors. Meanwhile, stress showed value $r=.801$. Based on the result of this study, the work stress, caused by the less entertainment, leisure time, and freedom at work also show a high percentage of workers in oil palm plantation which affect by the lack of essential happiness and comfort life. Working environment indicates that, lack of safety, employees feel at work. Some of the hazardous nature of work is exposed to the multiple risk factor of injuries and accidents. 
INTERNATIONAL JOURNAL OF ACADEMIC RESEARCH IN BUSINESS AND SOCIAL SCIENCES Vol. 10, No. 4, April, 2020, E-ISSN: 2222-6990 @ 2020 HRMARS

\section{Multiple Linear Regressions Analysis}

Table 4: Multiple Regression

\begin{tabular}{ll}
\hline Variables & $\mathbf{R}^{\mathbf{2}}$ \\
\hline Stress & 0.211 \\
Family issues & $\mathbf{0 . 2 5 8}$ \\
Working condition & 0.119 \\
Salary & 0.051 \\
\hline
\end{tabular}

Total

0.639

According to Table 4, the coefficient of determination $\left(R^{2}\right)$ of 0.639 , meaning 64 per cent of employee absenteeism can be showed by the independent variable of stress, family issues, working condition and salary. While the remaining 0.361 or 36.0 per cent is explained by other causes that are not included in this research model.

Family issues is the highest shares with $25.8 \%$ of the employee absenteeism, so it needs special attention. The term family issues include the tensions, challenges, and struggles individuals may perceive or feel related to their expectations, duties, requirements and behaviors in, for, and between each role. Negative spillover from family to work, in the form of divorcing, problems with children, or the death of a close friend or family member can also be broadened to encompass the negative effects of high levels of work-family role conflict or poor mental and physical health can have on various work-place outcomes. Improving working conditions with a resulting reduction in absenteeism might be a way to increase the labour supply of employee without significantly increasing new admissions or new recruits.

Those individuals reporting to experience high levels of some stress in their current position are more likely to have taken periods of absence from work than those without, the probability increasing with successively higher job stress. Stress is significantly increasing with working hours for all country groups and for local and migrant. Stress is also significantly positively increasing with income while significant evidence exists that experienced stress levels vary by task. Job stress is found to be significantly increasing with educational level, when married, when supervise people.

\section{Conclusion}

In conclusion, stress and family issues have a significant positive relationship with workers absenteeism with a strong correlation. Overall, all the four factors contribute to 64 percent to employees absenteeism. In this regard, family issues contribute almost 26 percent to this nonattendance. Thereby, the estate manager and team management should not ignore their employee welfare. The organization should give an appreciation to their workers with a gift card based on the lowest number of absences which may increase their motivation to attend the work. The organization should communicate with the workers frequently and speak with them face to face. It is the best way to show the appreciation towards them. The organization should supervise their labour in the workplace or outside of workplace to assure the stability, sustainability and security among society. Other than that, Yusof et al (2017) recommended the management team especially manager and assistant manager to acquire and seek knowledge with combining good facility to the 
INTERNATIONAL JOURNAL OF ACADEMIC RESEARCH IN BUSINESS AND SOCIAL SCIENCES Vol. 10, No. 4, April, 2020, E-ISSN: 2222-6990 @ 2020 HRMARS

employee. Since this study had only focused in Selandar Jasin Melaka, this survey is required to be conducted with other plantation workers and to other citizen to seek if there are similarities happen among the workers towards this issue. Meanwhile, further study to explore and seeking the factor of the problems contributing to the issue of absenteeism should be further discussed as the absenteeism may promote the organization facing a big loss of an income. It might be a good idea as it will help the organization recognize the problem and so to find a solution that may improve their style of management towards their workers.

\section{References}

Afzalur, R. M. C. P. (1996). A structural equations model of stress, locus of control, social support, psychiatric symptoms and propensity to leave a job. Journal Social Physhology, 136, 69-84. Retrieved from http://www.ncbi.nlm.nih.gov/pubmed/8851448

AIA. (2018). One Year Later: Malaysian Workforce Experience High Productivity Loss and WorkRelated Stress. Retrieved from www.healthiestworkplace.aia.com

Andale. (2014). Cronbach's alpha: Simple definition, use and interpretation. Retrieved from https://www.statisticshowto.com/cronbachs-alpha-spss/

Bernama. (2017). 67 days are lost to absenteeism per employee every year: Survey. New Straits Times. Retrieved from https://www.nst.com.my/news/nation/2017/11/309332/67-days-arelost-absenteeism-employee-every-year-survey

Drago, R., and Wooden, M. (2002). The determinants of labor absence: economic factors and workgroup norms. Industrial and Labor Relations Review, 45(4), 764-778.

Erickson, J. J., Martinengo, G., and Hill, E. (2010). Putting work and family experiences in context: Differences by family life stage. Human Relations, 63(7), 955-979.

Farahida, Z., Syahrizan, S., \& Firdaus, A. A. M. (2018). Negatives Impact Faced by Oil Palm Estate Management in managing Foreign Workers: A Case Study. International Journal of Academic Research in Business and Social Sciences, 8(9), 1525-1531. https://doi.org/10.6007/IJARBSS/v8i9/4863

FMT. (2020). Mental health issues among workers costing Malaysia RM14.4 billionitle. Free Malaysia Today (FMT). Retrieved from

https://www.freemalaysiatoday.com/category/nation/2020/02/17/mental-health-issuesamong-workers-costing-malaysia-rm14-4-billion/

Frick, B. M. M. (2008). Labor Market Institutions and Individual Absenteeism in the European Union: The Relative Importance of Sickness Benefit Systems and Employment Protection Legislation. Industrial Relations, 47(4), 505-529.

Hammer, L. T. C. (2003). Work-Family Role Conflict. Zicklin School of Business, Baruch college, CUNY,. Hanna, A. S., Menches, C. L., Sullivan, K. T., and Sargent, J. R. (2005). Factors affecting absenteeism in electrical construction. Journal of Construction Engineering and Management, 131(11), 12121218.

Hellriegel D, Slocum, J. W., Jr, \& Woodman, R. (2001). Organizational Behaviour (9th ed.). USA, SouthWestern: College Publishing.

Hinze, J., Ugwu, M., and Hubbard, L. (1985). Absenteeism in construction industry. Journal of Management in Engineering, 1(4), 188-200.

Kodjo, E. J. (2015). Gauging the Issue of Absenteeism in the Workplace : Evidence from the Public. 
INTERNATIONAL JOURNAL OF ACADEMIC RESEARCH IN BUSINESS AND SOCIAL SCIENCES

Vol. 10, No. 4, April, 2020, E-ISSN: 2222-6990 @ 2020 HRMARS

International Journal of Business and Social Science, 6(2), 65-71. Retrieved from http://ijbssnet.com/journals/Vol_6_No_2_February_2015/10.pdf

Kreitner, R., and Kinicki, A. (2004). Organizational Behaviour (6th ed.). New York: McGraw-Hill, Irwin. Krejcie, R. V., \& Morgan, D. W. (1970). Determining Sample Size for Research Activities. Educational and Psychological Measurement. https://doi.org/10.1177/001316447003000308

Nunnaly, J. (1978). Psychometric theory. New York: McGraw-Hill.

Pfeifer, C. (2010). Impact of wages and job levels on worker absenteeism. International Journal of Manpower, 31(1), 59-72. https://doi.org/10.1108/01437721011031694

Rajbhandary, S., \& Basu, K. (2010). Working conditions of nurses and absenteeism: Is there a relationship? An empirical analysis using National Survey of the Work and Health of Nurses. Health Policy, 97(2-3), 152-159. https://doi.org/10.1016/j.healthpol.2010.04.010

Tan, T. (2020, February 18). Mental health hurts economy badly. The Star. Retrieved from https://www.thestar.com.my/news/nation/2020/02/18/mental-health-hurts-economy-badly 